\title{
STRATEGI PENINGKATAN PENERIMAAN PENDAPATAN PAJAK REKLAME DIKABUPATEN BOGOR
}

\section{Strategy of Improvement Advertising Revenue Income Tax In Bogor District}

\author{
Indah Ayu Sulviane 1, Harianto ${ }^{2}$, dan Dedi Budiman Hakim ${ }^{3}$ \\ 1 Staf Bagian Perundang-undangan, Sekretariat Daerah, Kabupaten BogorE-mail: iasulviane@gmail.com \\ ${ }^{2}$ Staff Pengajar Departemen Agribisinis. Fakultas Ekonomi \& Manajemen IPB.E-mail: harianto_ipb@yahoo.com \\ 3 Staff Pengajar Departemen Ilmu Ekonomi. Fakultas Ekonomi \&Manajemen IPB.E-mail: dedihakim@gmail.com
}

\begin{abstract}
Implementation for fiscal decentralitation, local government that required excavation and development of the area and potential revenue sources to increase regional revenue.The objective of this research is to analyze the factors that influence the potential of advertisement tax revenue, reviewing management organization of advertisement tax is implemented, analyzed the taxpayer perceptions of the advertisement tax and revenue enhancement strategy billboard tax in Bogor regency.The data used are secondary and primary data was analyzed by descriptive quantitative and qualitative. The analytical method used is a regression method, the calculation of Efficiency and Effectiveness taxes. As for the design of this research program using Analysis IFE, EFE and IE, SWOT Analysis and Analysis QSPM.Results of the discussion, in the realization of the tax revenue target advertisements Bogor regency government always exceed the achievement of the targets, with the exception of 2006, when the realization is not achieved then the effective rate also decreased and the percentage of tax efficiency at the Bogor Regency advertisement in 2000 - 2012 looks good and the smaller the ratio efficiency means that the performance of the Bogor regency government for the better collection of advertisement tax.Based on the partial test table, budget, number of employees, regulatory and tax payers have a significant impact on tax revenue billboard on the real level of $10 \%$. Constraints faced in collecting data on the potential of the advertisement tax is the lack of accurate data due to the limited ability of local government officials, the need for legal certainty in the billboard tax management.The draft strategy are as follows 1) conduct outreach and education on an ongoing basis to increase public awareness, 2) build a system of valid and accurate data; 3) give reward and punishment.
\end{abstract}

Keywords: Strategy, Regional Revenue, Advertising Tax

\begin{abstract}
ABSTRAK
Wujud otonomi dan desentralisasi fiscal, pemerintah daerah berusaha melakukan penggalian dan pengembangan sumber pendapatan potensial untuk meningkatkan pendapatan asli daerah.Tujuan penelitian menganalisis faktor-faktor yang mempengaruhi penerimaan pajak reklame, mengkaji manajemen penyelengaraan pajak reklame, menganalisis persepsi masyarakat terhadap pajak reklame dan menyusun strategi peningkatan pendapatan pajak reklame di Kabupaten Bogor.Data yang digunakan data sekunder dan primer, dianalisis secara deskriftif kuantitatif, kualitatif. Metode analisis yang digunakan Regresi, Efisiensi dan Efektivitas pajak. Perancangan program menggunakan Analisis IFE, EFE dan IE, Analisis SWOT dan Analisis QSPM.Hasil pembahasan, dalam merealisasikan target pendapatan pajak reklame selalu melebihi target yang ditetapkan, dengan pengecualian tahun 2006, ketika realisasi tidak tercapai maka efektivitas mengalami penurunan dan persentase efisiensi pajak reklame di Kabupaten Bogor tahun 2000-2012 terlihat baik dan semakin kecil rasio efisiensi mengandung arti kinerja pemerintah Kabupaten Bogor untuk pemungutan pajak reklame semakin baik.Berdasarkan tabel uji parsial, anggaran, pegawai, peraturan dan wajib pajak memiliki pengaruh yang signifikan terhadap penerimaan pajak reklame pada taraf nyata $10 \%$. Kendala yang dihadapi yaitu kurangnya data yang akurat, keterbatasan kemampuan aparat, masih kurang nya kesadaran masyarakat dan perlunya ada kepastian hukum. Rancangan strategi adalah 1) melakukan sosialisasi penyuluhan secara berkesinambungan 2) membangun sistem data yang valid dan akurat 3) memberikan reward dan punishment sesuai ketentuan.
\end{abstract}

Kata Kunci : Strategi, Pendapatan Asli Daerah, Pajak Reklame 


\section{PENDAHULUAN}

\section{Latar Belakang}

Kabupaten Bogor mempunyai letak yang sangat strategis, sebagai daerah penyangga (buffer zone) dan penyeimbang (counter magnet) ibukota Jakarta. Tumbuh dan berkembang aktivitas sosial ekonomi yang potensial dan prospektik. Kegiatan pembangunan di Kabupaten Bogor akan semakin meningkat yang berarti dana yang harus dihimpun oleh Pemerintah Kabupaten Bogor harus semakin banyak, sehingga dibutuhkan penggalian dan pengembangan daerah dan sumber-sumber pendapatan potensial guna menunjang pelaksanaan program pembangunan untuk mencukupi semua kebutuhan daerah.

Pada Tahun 2010 Pemerintah Kabupaten Bogor mengeluarkan regulasi mengenai Pajak dan Retribusi Daerah yang disesuaikan dengan Undang-Undang Nomor 28 Tahun 2009 tentang Pajak Daerah dan Retribusi Daerah. Peraturan daerah tersebut adalah legalitas yang mengatur pajak di Kabupaten Bogor.Adanya penyelarasan tersebut tentunya akan menambah potensi PAD yang selama ini sudah ada, sehingga diharapkan hasil pendapatan PAD dari pajak dan retribusi daerah akan meningkat.
Kondisi dan permasalahan yang ditemui dalam pengelolaan keuangan dan pendapatan daerah pada masing-masing daerah sangat berbeda, hal ini dikarenakan perbedaan tersedianya sumberdaya, tingkat kemajuan serta kemampuan sumbersumber yang ada. Dalam rangka upaya pendayagunaan aparatur, termasuk di dalamnya pejabat dan staf yang mengelola keuangan dan pendapatan daerah, perlu diberikan peningkatan pengetahuan dan keterampilan untuk menggali potensi sumber pendapatan daerah yang ada serta mengelola administrasi keuangan daerah secara baik, sehingga dapat digunakan secara efisien dalam pembangunan daerah.

Berdasarkan hasil rekapitulasi trend pertumbuhan realisasi pajak daerah di Kabupaten Bogor dalam kurun waktu 2003-2008 (tabel 1), dapat dilihat bahwa ada 3 jenis pajak daerah yang menempati urutan teratas dalam rata-rata pertumbuhan realisasi yaitu Pajak Parkir, Pajak Reklame dan Pajak Hotel.Ini merupakan trend yang cukup positif bagi Kabupaten Bogor. Tetapi trend positif ini tentunya sangat dipengaruhi oleh potensi pajak daerah yang masih harus di gali dan dimaksimalkan oleh Pemerintah Kabupaten Bogor sehingga perlu dilakukan kajianstrategi peningkatan penerimaan pendapatan dari pajak reklame di Kabupaten Bogor.

Tabel 1. Rekapitulasi Trend Pertumbuhan Realisasi Pendapatan Daerah Kabupaten Bogor dan Pajak Daerah tahun 2003-2008

\begin{tabular}{|c|c|c|c|c|c|c|c|}
\hline \multirow{2}{*}{\multicolumn{2}{|c|}{ Uraian Pendapatan Daerah }} & \multicolumn{5}{|c|}{ Pertumbuhan Realisasi Pendapatan Daerah } & \multirow{2}{*}{$\begin{array}{c}\text { Rata-Rata Pertumbuhan } \\
\text { Realisasi }\end{array}$} \\
\hline & & $\begin{array}{l}2003- \\
2004\end{array}$ & $\begin{array}{l}2004- \\
2005\end{array}$ & $\begin{array}{l}2005- \\
2006\end{array}$ & $\begin{array}{l}2006- \\
2007\end{array}$ & $\begin{array}{l}2007- \\
2008\end{array}$ & \\
\hline \multicolumn{2}{|r|}{ Pendapatan Asli Daerah } & 11,64 & 19,95 & 15,38 & 15,33 & 15,92 & 15,65 \\
\hline \multicolumn{2}{|r|}{ PAJAK DAERAH } & 14,91 & 17,03 & 12,32 & 17,51 & 12,62 & 14,88 \\
\hline 1 & Pajak Hotel & 12,05 & 17,15 & 26,07 & 13,42 & 20,77 & 17,89 \\
\hline 2 & Pajak Restoran & 19,55 & 22,53 & 5,68 & 15,60 & 16,80 & 16,03 \\
\hline 3 & Pajak Hiburan & 18,65 & 9,16 & 5,90 & 23,63 & 28,58 & 17,18 \\
\hline 4 & Pajak Reklame & 41,43 & 60,93 & 5,08 & 23,31 & 6,50 & 27,45 \\
\hline \multirow[t]{3}{*}{5} & Pajak Penerangan Jalan & 11,02 & 14,80 & 16,13 & 6,23 & 10,69 & 11,77 \\
\hline & a PLN & 9,88 & 18,97 & 20,59 & 6,56 & 11,26 & 13,45 \\
\hline & b Non PLN & 18,45 & 10,51 & 19,79 & 2,31 & 3,47 & 1,22 \\
\hline \multirow{2}{*}{\multicolumn{2}{|c|}{ 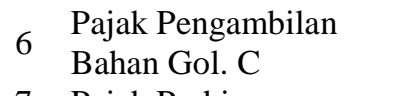 }} & 18,17 & 13,81 & 5,75 & 39,98 & 11,23 & 17,79 \\
\hline & Pajak Parkir & 50,58 & 37,03 & 19,62 & 24,41 & 95,03 & 45,33 \\
\hline 8 & $\begin{array}{l}\text { Pajak Sarang Burung } \\
\text { Walet }\end{array}$ & 29,88 & 14,47 & 5,62 & 1,46 & 9,34 & 0,20 \\
\hline
\end{tabular}

Sumber : Dinas Pendapatan, Keuangan dan Barang Daerah (DPKBD) Kabupaten Bogor. 
Berdasarkan latar belakang dan perumusan masalah, maka tujuan utama dari kajian ini adalah menganalisis bagaimana meningkatkan pajak daerah di Kabupaten Bogor agar dapat menunjang pembiayaan penyelenggaraan pembangunan dan pemerintahan dan untuk menjawab tujuan utama tersebut, maka tujuan khusus dari kajian ini adalah :

1. Menganalisis faktor-faktor apa saja yang mempengaruhi potensi penerimaan pajak reklame;

2. Mengkaji manajemen penyelengaraan pajak reklame yang dilaksanakan;

3. Menganalisis persepsi wajib pajak terhadap pajak reklame;

4. Menyusun strategi peningkatan pendapatan pajak reklame di kabupaten bogor.

\section{TINJAUAN PUSTAKA}

Syahruddin (2006) mendefinisikan desentralisasi fiskal sebagai kewenangan (authority) dan tanggungjawab (responsibility) dalam penyusunan, pelaksanaan, dan pengawasan anggaran daerah (APBD) oleh pemerintah daerah. Desentralisasi fiskal merupakan salah satu komponen utama dari desentralisasi. Apabila pemerintah daerah melaksanakan fungsinya secara efektif dan diberikan kebebasan dalam pengambilan keputusan penyediaan pelayanan di sektor publik, maka mereka harus didukung sumbersumber keuangan yang memadai yang berasal dari Pendapatan Asli Daerah (PAD) termasuk surcharge of taxes, bagi hasil pajak dan bukan pajak, pinjaman, maupun subsidi dari pemerintah pusat.

Lutfi (2002) menyatakan Pajak daerah yang diterapkan dalam rangka pelaksanaan desentralisasi fiskal diharapkan mampu memberikan penerimaan yang signifikan dan berdampak pada kemampuan daerah dalam membiayai tanggung jawab fiskalnya. Untuk memperoleh penerimaan pajak daerah yang cukup signifikan dalam rangka desentralisasi fiskal, maka daerah harus memiliki kewenangan untuk menetapkan tarif pajak daerah yang tepat.

\section{Sumber-Sumber Penerimaan Daerah}

Sumber penerimaan daerah dalam melaksanakan desentralisasi berdasarkan Undang-Undang Nomor 33 tahun 2004 tentang perimbangan keuangan antara pusat dan daerah, terdiri dari pendapatan daerah dan pembiayaan yang terdiri dari Pendapatan Asli Daerah (PAD) yang terdiri dari, Pajak daerah, Retribusi daerah, Hasil perusahaan milik daerah dan hasil pengelolaan kekayaan daerah yang dipisahkan;dan Lain-lain PAD yang sah, Dana Perimbangan yang terdiri dari Dana Bagi Hasil, dana Alokasi Umum (DAU), dan Dana Alokasi Khusus (DAK), Pinjaman Daerah danLain-lain PAD yang sah. Selanjutnya pembiayaan daerah bersumber dari sisa lebih perhitungan anggaran daerah, penerimaan pinjaman daerah, dana cadangan daerah dan hasil penjualan kekayaan daerah yang dipisahkan.

\section{Definisi Pajak dan pajak Daerah}

Pajak menurutSoemitro, adalah
iuran rakyat kepada kas Negara berdasarkan undang-undang (yang dapat dipaksakan) dengan tidak mendapat jasa timbal (kontraprestasi) yang langsung dapat ditunjukan dan yang digunakan untuk membayar pengeluaran umum. Pengertian pajak daerah berdasarkan Undang-Undang Nomor 28 Tahun 2009 tentang Pajak Daerah dan Retribusi Daerah adalah kontribusi wajib kepada daerah yang terutang oleh orang pribadi atau badan yang bersifat memaksa berdasarkan Undang-Undang, dengan tidak mendapatkan imbalan secara langsung dan digunakan untuk keperluan daerah bagi sebesar-besarnya kemakmuran rakyat

\section{Manajemen Pajak Reklame di Kabupaten Bogor}

Di Kabupaten Bogor, pemungutan pajak reklame menerapkan sistem officiaassesment. Pemda menghitung. memperhitungkan dan menetapkan pajak 
terutang. Surat pemberitahuan pajak daerah (SPTPD) disampaikan kepada Subyek Pajak, paling lambat 10 hari sejak berakhirnya rnasa pajak. Pembayaran pajak di kas daerah atau tempat lain ditunjuk bupati sesuai waktu yang ditentukan dalam SPTPD.

Pajak reklame adalah pajak atas penyelenggaraan reklame. Reklame adalah benda, alat, perbuatan, atau media yang bentuk dan corak ragamnya dirancang untuk tujuan komersial memperkenalkan, menganjurkan, mempromosi -kan, atau untuk menarik perhatian umum terhadap barang, jasa, orang, atau badan, yang dapat dilihat, dibaca, didengar, dirasakan, dan/atau dinikmati oleh umum.Subyek Pajak adalah orang pribadi atau badan yang dapat dikenakan pajak. Wajib Pajak adalah orang pribadi atau badan, meliputi pembayar pajak, pemotong pajak, dan pemungut pajak, yang mempunyai hak dan kewajiban perpajakan sesuai dengan ketentuan peraturan perundang-undangan perpajakan daerah.

Obyek pajak adalah semua penyelenggaraan Reklame, seperti halnya reklame papan/billboard/videotron /megatron dan sejenisnya, reklame kain, reklame melekat, stiker, reklame selebaran, reklame berjalan termasuk pada kendaraan, reklame udara, reklame apung, reklame suara, reklame film/slide, dan reklame peragaan.Dalam manajemen pelaksanaan penyelenggaraan pajak reklame di Kabupaten Bogor, tentunya sangat dipengaruhi oleh situasi dan kebijakan yang diterapkan. Faktor-faktor yang diduga akan mempunyai pengaruh yang positif dan signifikan terhadap penerimaan pajak reklame adalah Anggaran untuk penyelenggaraan Pajak, Jumlah Pegawai penyelenggaraan pajak dan jumlah Peraturan yang ditetapkan dalam penyelenggaraan pajak serta jumlah wajib pajak.

\section{Lokasi dan Waktu Kajian}

Kajian ini dilaksanakan di Kabupaten Bogor. Penentuan lokasi dilakukan secara purposive dengan lokasi yang diharapkan dapat mewakili lokasi pemasangan reklame yang ada di Kabupaten Bogor berdasarkan peta lokasi titik-titik pemasangan reklame yaitu di Kecamatan Ciawi, Kecamatan Parung, Kecamatan Cibinong dan Kecamatan Dramaga. Waktu pengambilan dan pengolahan data dilaksanakan selama empat bulan, yakni bulan Maret sampai dengan bulan Juni 2013.

\section{Pelaksanaan Survey}

1. Pada kuesioner responden masyarakat dan petugas lapangan, dilakukan dengan metode Survei purposive sampling berdasarkan karekteristik data Subyek Pajak yang dilakukan dengan dua cara dalam pengambilan data responden, yaitu :

a. Melakukan pengambilan data responden di unit kerja Dinas Pendapatan Daerah Kabupaten Bogor, Dinas Kebersihan dan Pertamanan Kabupaten Bogor serta Badan Perizinan Terpadu, sehingga data yang didapatkan secara acak tergantung kepada responden yang datang sendiri ke unit kerja tersebut dan mensurvey petugas lapangan yang bertugas di unit kerja tersebut.

b. Melakukan pengambilan data responden secara langsung di empat wilayah kecamatan yang diharapkan dapat mewakili lokasi pemasangan reklame yang ada di Kabupaten Bogor, berdasarkan peta lokasi titik-titik pemasangan reklame, yaitu Kecamatan Ciawi, Kecamatan Parung, Kecamatan Cibinong dan Kecamatan Dramaga.

Tabel 3. Responden Masyarakat dan Petugas Lapangan

\begin{tabular}{lccc}
\hline \multicolumn{2}{c}{ Karakteristik } & Jumlah & Total \\
\hline \multirow{2}{*}{ Wajib Pajak } & Laki-Laki & 59 & \multirow{2}{*}{84} \\
Belum & Perempuan & 25 & \\
Wajib Pajak & Laki-Laki & 72 & 100 \\
Petugas & Perempuan & 28 & \\
Lapangan & Laki-Laki & 15 & 19 \\
\hline \multicolumn{5}{c}{ Perempuan } & 4 & 203 \\
\hline
\end{tabular}




\section{METODE PENELITIAN}

\section{Kerangka Pemikiran}

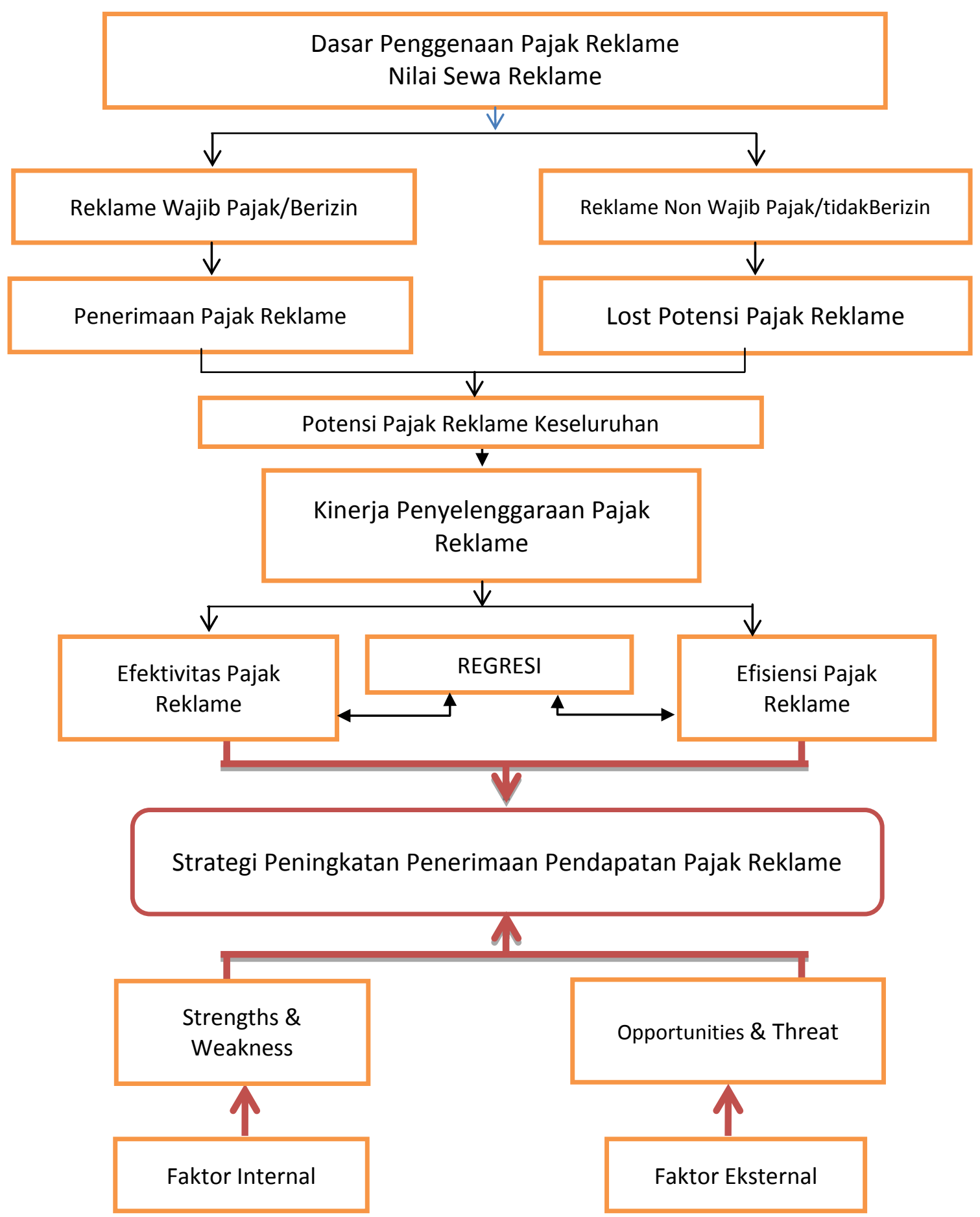

Gambar 1. Kerangka Penelitian 
2. Pada kuesioner dengan responden pakar yang dilakukan dengan metode purposive sampling, berdasarkan pertimbangan bahwa responden yang bersangkutan dinilai memiliki kepentingan dan/atau kompetensi dan/atau keterlibatan dalam proses perencanaan sampai dengan evaluasi manajemen penyelenggaraan pajak reklame.

Tabel 4. Responden Pakar

\begin{tabular}{lc}
\hline \multicolumn{1}{c}{ Instansi } & Jumlah Pakar \\
\hline DPRD & 1 orang \\
Setda & 1 orang \\
Bappeda & 1 orang \\
BPT & 1 orang \\
Dipenda & 1 orang \\
DKP & 1 orang \\
\hline \multicolumn{2}{r}{$\quad$ Total } \\
\hline
\end{tabular}

Metode penelitian yang digunakan adalah adalah studi pustaka dan studi lapangan dengan cara survey dan dokumentasi dengan mengumpulkan dokumen sebagai informasi yang akan diteliti.

\section{Metode Pengolahan dan Analisis Data}

Dalam kajian ini menggunakan metode kuantitatif dan kualitatif. Pada langkah terakhir dalam kajian ini akan digunakan beberapa metode sebagai perumusan strategi dan rancangan program seperti Analisis IFE, Analisis EFE, Analisis IE, Analisis SWOT dan Analisis QSPM.

Tabel 5. Data dan Metode Analisis

\begin{tabular}{|c|c|c|c|}
\hline \multirow{2}{*}{ Tujuan Kajian } & \multicolumn{2}{|c|}{ Data } & \multirow{2}{*}{ Metode analisis } \\
\hline & Jenis & Sumber & \\
\hline $\begin{array}{lcc}\text { 1. Menganalisis } & \text { faktor-faktor } & \text { yang } \\
\text { mempengaruhi } & \text { penerimaan } & \text { pajak } \\
\text { reklame di Kabupaten Bogor } & \end{array}$ & $\begin{array}{l}\text { - } \text { RPJMD } \\
\text { - } \text { APBD } \\
\text { - Laporan Dinas/data } \\
\text { primer dan sekunder }\end{array}$ & $\begin{array}{l}\text { - Dipenda } \\
\text { - BPS }\end{array}$ & $\begin{array}{l}\text { Deskriptif } \\
\text { Kuantitatif, } \\
\text { Regresi } \\
\text { Efisiensi dan } \\
\text { Efektifiktas }\end{array}$ \\
\hline $\begin{array}{l}\text { 2. Menganalisis manajemen } \\
\text { penyelenggaraan pajak reklame yang } \\
\text { dilakukan oleh Pemerintah Kabupaten } \\
\text { Bogor }\end{array}$ & $\begin{array}{l}\text { - Kuesioner/Survey } \\
\text { - Data primer Data } \\
\text { sekunder }\end{array}$ & $\begin{array}{l}\text { - Responden Petugas } \\
\text { Lapangan Dipenda } \\
\text { - } \text { DKP } \\
\text { - } \text { BPT }\end{array}$ & $\begin{array}{c}\text { Deskriptif, } \\
\text { Purposive sampling }\end{array}$ \\
\hline $\begin{array}{l}\text { 3. bagaimana persepsi dari para Wajib } \\
\text { Pajak maupun objek pajak yang } \\
\text { potensial perlu dinilai secara langsung } \\
\text { agar secara langsung masyarakat } \\
\text { sebagai pihak yang dipungut pajak }\end{array}$ & $\begin{array}{l}\text { - Kuesioner/Survey } \\
\text { - Data primer }\end{array}$ & $\begin{array}{ll}\text { - } & \text { Responden } \\
\text { - Wajib Pajak } \\
\text { - } \text { Masyarakat }\end{array}$ & Purposive sampling \\
\hline 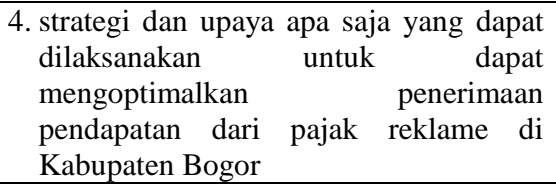 & $\begin{array}{l}\text { - Kuesioner/Survey } \\
\text { - Data primer }\end{array}$ & 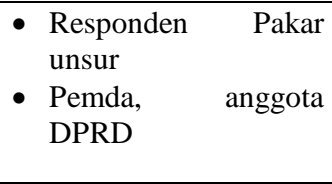 & $\begin{array}{l}\text { Purposive sampling, } \\
\text { Analisis IFE, EFE } \\
\text { dan IE, SWOT, } \\
\text { QSPM }\end{array}$ \\
\hline
\end{tabular}

\section{HASIL DAN PEMBAHASAN}

\section{Efektivitas Pajak Reklame Kabupaten Bogor}

Efektivitas penerimaan pajak reklame dapat diketahui dan dibandingkan untuk melihat bagaimana kinerja pemerintah Kabupaten Bogor dalam melaksanakan pemungutan pajak reklame. Tinggi nya efektivitas pajak reklame bisa menunjukan tingginya upaya-upaya yang sudah dilakukan oleh pemerintah
Kabupaten Bogor dalam mengintensifkan pemungutan pajak reklame. 
Tabel 6. Efektivitas Pajak Reklame di Kabupaten Bogor

\begin{tabular}{ccccc}
\hline No & Tahun & Target & Realisasi & Efektivitas \\
\hline 1 & 2000 & $450.000 .000,00$ & $538.187 .843,40$ & 1,196 \\
2 & 2001 & $1.100 .000 .000,00$ & $1.104 .999 .658,04$ & 1,005 \\
3 & 2002 & $1.750 .000 .000,00$ & $1.811 .173 .769,71$ & 1,035 \\
4 & 2003 & $2.500 .000 .000,00$ & $2.644 .285 .116,92$ & 1,058 \\
5 & 2004 & $3.500 .000 .000,00$ & $3.739 .755 .522,18$ & 1,069 \\
6 & 2005 & $6.000 .111 .000,00$ & $6.018 .259 .130,89$ & 1,003 \\
7 & 2006 & $6.500 .111 .000,00$ & $6.324 .186 .424,00$ & 0,973 \\
8 & 2007 & $7.087 .950 .000,00$ & $7.669 .278 .710,00$ & 1,082 \\
9 & 2008 & $7.650 .000 .000,00$ & $10.016 .285 .493,00$ & 1,309 \\
10 & 2009 & $8.250 .000 .000,00$ & $8.260 .254 .289,00$ & 1,001 \\
11 & 2010 & $7.814 .400 .000,00$ & $8.015 .331 .887,00$ & 1,026 \\
12 & 2011 & $8.500 .000 .000,00$ & $8.558 .040 .267,00$ & 1,007 \\
13 & 2012 & $9.500 .000 .000,00$ & $10.045 .280 .964,00$ & 1,057 \\
\hline
\end{tabular}

Sumber : Data Sekunder diolah

Terlihat bahwa dalam merealisasikan target pendapatan untuk pajak reklame pemerintah Kabupaten Bogor selalu pencapaiannya melebihi target yang ditetapkan dari setiap tahunnya, dengan pengecualian pada tahun 2006, ketika realisasi tidak tercapai maka angka efektivitas juga mengalami penurunan.

\section{Efisiensi Pajak Reklame Kabupaten Bogor}

Tingkat efisiensi dinyatakan dalam presentase adalah perbandingan antara upah pungut pajak reklame dengan realisasi pajak reklame. Tingkat efisiensi akan semakin tinggi bila biaya untuk merealisasikan penerimaan ditekan serendah mungkin.

Tabel 7. Efisiensi Pajak Reklame di Kabupaten Bogor

\begin{tabular}{cccccc}
\hline No & Tahun & Target & Realisasi & $\begin{array}{c}\text { Uppr/Insentif (5\% } \\
\text { Dari Target) }\end{array}$ & Efisiensi \\
\hline 1 & 2000 & $450.000 .000,00$ & $538.187 .843,40$ & $22.500 .000,00$ & 0,042 \\
2 & 2001 & $1.100 .000 .000,00$ & $1.104 .999 .658,04$ & $55.000 .000,00$ & 0,050 \\
3 & 2002 & $1.750 .000 .000,00$ & $1.811 .173 .769,71$ & $87.500 .000,00$ & 0,048 \\
4 & 2003 & $2.500 .000 .000,00$ & $2.644 .285 .116,92$ & $125.000 .000,00$ & 0,047 \\
5 & 2004 & $3.500 .000 .000,00$ & $3.739 .755 .522,18$ & $175.000 .000,00$ & 0,047 \\
6 & 2005 & $6.000 .111 .000,00$ & $6.018 .259 .130,89$ & $300.005 .550,00$ & 0,050 \\
7 & 2006 & $6.500 .111 .000,00$ & $6.324 .186 .424,00$ & $325.005 .550,00$ & 0,051 \\
8 & 2007 & $7.087 .950 .000,00$ & $7.669 .278 .710,00$ & $354.397 .500,00$ & 0,046 \\
9 & 2008 & $7.650 .000 .000,00$ & $10.016 .285 .493,00$ & $382.500 .000,00$ & 0,038 \\
10 & 2009 & $8.250 .000 .000,00$ & $8.260 .254 .289,00$ & $412.500 .000,00$ & 0,050 \\
11 & 2010 & $7.814 .400 .000,00$ & $8.015 .331 .887,00$ & $390.720 .000,00$ & 0,049 \\
12 & 2011 & $8.500 .000 .000,00$ & $8.558 .040 .267,00$ & $425.000 .000,00$ & 0,050 \\
13 & 2012 & $9.500 .000 .000,00$ & $10.045 .280 .964,00$ & $475.000 .000,00$ & 0,047 \\
\hline
\end{tabular}

Sumber : Data Sekunder diolah 
Persentase efisiensi pajak reklame di Kabupaten Bogor pada tahun 2000-2012 terlihat baik dansemakin kecil rasio efisiensi mengandung arti bahwa kinerja pemerintah Kabupaten Bogor untuk pemungutan pajak reklame semakin baik.

Faktor-faktor yang mempengaruhi penerimaan pajak reklame di Kabupaten Bogor

Hasil perhitungan regresi sebagai berikut:

\begin{tabular}{cccccc}
\multicolumn{7}{l}{ Tabel 8. Hasil Uji Anova } & & & \\
\hline $\begin{array}{c}\text { Sumber } \\
\text { Keragam } \\
\text { an }\end{array}$ & $\begin{array}{c}\text { Deraj } \\
\text { at } \\
\text { bebas }\end{array}$ & $\begin{array}{c}\text { Jumlah } \\
\text { Kuadrat }\end{array}$ & $\begin{array}{c}\text { Kuadrat } \\
\text { Tengah }\end{array}$ & $\begin{array}{c}\text { F } \\
\text { hitung }\end{array}$ & $\begin{array}{c}\text { Nilai } \\
\text { p }\end{array}$ \\
\hline Regresi & 4 & $\begin{array}{c}0,01246 \\
5\end{array}$ & $\begin{array}{c}0,00311 \\
6\end{array}$ & $\begin{array}{c}2769,93 \\
0\end{array}$ & 0,01 \\
Galat & 1 & $\begin{array}{c}0,00000 \\
1\end{array}$ & $\begin{array}{c}0,00000 \\
1\end{array}$ & & 4 \\
Total & 5 & $\begin{array}{c}0,01246 \\
6\end{array}$ & & & \\
\hline
\end{tabular}

Hipotesis

$\mathrm{HO}: \beta_{0}=\beta_{1}=\beta_{2}=\beta_{3}=\beta_{4}=0$

H1 : Minimal ada $\beta_{i} \neq 0, i=1,2,3,4$

Karena nilai p sebesar 0,014 lebih kecil dari 0,05 maka tolak H0. Artinya minimal ada satu peubahpenjelas yang mempengaruhi penerimaan pajak reklame.

Berdasarkan tabel uji parsial, anggaran, jumlah pegawai, peraturan dan wajib pajak memiliki pengaruh yang signifikan terhadap penerimaan pajak reklame pada taraf nyata $10 \%$. Hal ini dikarenakan nilai p lebih kecil dari 0,1 sehingga tolak H0. Pada faktor jumlah anggaran memiliki nilai koefisien sebesar 0,07, artinya penurunan anggaran satu satuan akan meningkatkan penerimaan pajak 0,07 satu satuan.

Tabel 9. Hasil Uji Parsial

\begin{tabular}{cccccc}
\hline Sumber Keragaman & Koef & SE Koef & T hitung & Nilai p & VIF \\
\hline Konstanta & 10,121 & 0,035 & 291,190 & 0,002 & \\
Jumlah Anggaran & $-0,070$ & 0,006 & $-11,940$ & 0,053 & 4,9 \\
Jumlah Pegawai & $-0,295$ & 0,005 & $-63,720$ & 0,010 & 1,8 \\
Jumlah Peraturan & 0,950 & 0,011 & 89,010 & 0,007 & 2,5 \\
Jumlah Wajib Pajak & 0,143 & 0,008 & 18,580 & 0,034 & 3 \\
\hline
\end{tabular}

Ket: Koef $=$ koefisien

Faktor jumlah pegawai memiliki nilai koefisien sebesar -0,295, artinya penurunan jumlah pegawai satu satuan akan meningkatkan 0,295 satu satuan penerimaan pajak reklame. Dengan kata lain, diperlukan peningkatan efisiensi dan efektifitas terhadap jumlah pegawai. Sedangkan faktor jumlah peraturan memiliki nilai koefisien sebesar 0,950, artinya peningkatan jumlah peraturan satu satuan maka akan meningkatkan 0,950 satu satuan penerimaan pajak reklame. Faktor jumlah wajib pajak memiliki nilai koefisien sebesar 0,143, artinya peningkatan jumlah wajib pajak satu satuan akan meningkatkan penerimaan pajak reklame 0,143 satu satuan.

\section{Analisis Manajemen Penyelenggaraan Pajak Reklame}

Pada kuesioner dengan responden pakar yang dilakukan secara purposive sampling, berdasarkan pertimbangan bahwa responden dinilai memiliki kepentingan dan/atau kompetensi dan/atau keterlibatan dalam proses perencanaan sampai dengan evaluasi manajemen penyelenggaraan pajak reklame.

Tabel 10. Kendala dalam Melakukan Pendataan Potensi Pajak Reklame

\begin{tabular}{clcc}
\hline No & \multicolumn{1}{c}{ Kriteria } & $\begin{array}{c}\text { Frekuensi } \\
\text { Jawaban }\end{array}$ & $\%$ \\
\hline 1 & Data kurang akurat & 6 & 16,7 \\
2 & Aparat lemah & 6 & 16,7 \\
3 & Kesadaran masyarakat & 6 & 16,7 \\
\hline
\end{tabular}

Kendala yang dihadapi pemerintah daerah dalam melakukan pendataan potensi pajak reklame yaitu kurangnya data yang akurat karena keterbatasan kemampuan aparat pemerintah daerah serta masih kurang nya kesadaran masyarakat. 
Tabel 11.Keterlibatan Pihak-Pihak Dalam Penentuan Besarnya Potensi Pajak Reklame

\begin{tabular}{clccccccc}
\hline No & Keterlibatan & $\begin{array}{c}\text { Sangat } \\
\text { Tinggi }\end{array}$ & Tinggi & Sedang & Rendah & $\begin{array}{c}\text { Sangat } \\
\text { Rendah }\end{array}$ & $\begin{array}{c}\text { Range } \\
\text { Keterlibatan }\end{array}$ & $\begin{array}{c}\text { Kategori Tingkat } \\
\text { Keterlibatan }\end{array}$ \\
\hline 1 & DPRD & 4 & 1 & 0 & 1 & 0 & 26 & Sangat Tinggi \\
2 & Setda & 2 & 4 & 0 & 0 & 0 & 26 & Sangat Tinggi \\
3 & Bapeda & 1 & 3 & 2 & 0 & 0 & 23 & Tinggi \\
4 & BPT & 1 & 2 & 3 & 0 & 0 & 22 & Tinggi \\
5 & Dipenda & 5 & 1 & 0 & 0 & 0 & 29 & Sangat Tinggi \\
6 & DKP & 1 & 5 & 0 & 0 & 0 & 25 & Tinggi \\
\hline
\end{tabular}

Berdasarkan hasil survey, keterlibatan Dipenda sangat tinggi karena yang melakukan perhitungan dan penetapan potensi target sesuai dengan salah satu tupoksi Dipenda, keterlibatan DPRD dalam penentuan besarnya potensi pajak reklame sangat tinggi karena dalam rapat-rapat panitia anggaran DPRD lah dibahas dan ditentukan berapa penentuan target PAD serta dibahas potensi-potensi PAD. Setda sebagai representasi dari Bupati sebagai Kepala Daerah, juga dianggap memiliki tingkat keterlibatan Sangat Tinggi dalam penentuan besarnya potensi pajak

Tabel 12. Persepsi Responden terhadap Potensi Pajak Reklame

\begin{tabular}{|c|c|c|c|c|c|c|}
\hline $\begin{array}{c}\text { Penil } \\
\text { aian } \\
\text { Resp } \\
\text { onde } \\
\text { n }\end{array}$ & $\begin{array}{c}\text { San } \\
\text { gat } \\
\text { Real } \\
\text { istik }\end{array}$ & $\begin{array}{l}\text { Real } \\
\text { istik }\end{array}$ & $\begin{array}{c}\text { Tida } \\
\mathrm{k} \\
\text { Real } \\
\text { istik }\end{array}$ & $\begin{array}{c}\text { San } \\
\text { gat } \\
\text { Tida } \\
\text { k } \\
\text { Real } \\
\text { istik }\end{array}$ & $\begin{array}{c}\text { Ran } \\
\text { ge } \\
\text { Pers } \\
\text { epsi }\end{array}$ & $\begin{array}{c}\text { Kate } \\
\text { gori } \\
\text { Ting } \\
\text { kat } \\
\text { Pers } \\
\text { epsi }\end{array}$ \\
\hline $\begin{array}{c}\text { Perse } \\
\text { psi }\end{array}$ & 0 & 4 & 1 & 1 & 19 & $\begin{array}{c}\text { Real } \\
\text { istis }\end{array}$ \\
\hline
\end{tabular}

Adanya persepsi satu orang yang menjawab tidak realistis serta satu orang pula yang menjawab sangat tidak realistis terhadap potensi pajak reklame mencerminkan bahwa sebenarnya target potensi pajak reklame di Kabupaten Bogor masih jauh dari harapan atau kenyataan yang sebenarnya

\section{Analisis Persepsi Masyarakat}

Analisis persepsi masyarakat bertujuan untuk mengetahui bagaimana persepsi masyarakat mengenai manajemen pajak reklame yang dilakukan oleh pemerintah Kabupaten Bogor.Hal ini dilakukan karena selama ini belum adanya kajian mengenai persepsi masyarakat terhadap pajak yang dikenakan maupun lainnya.

Tabel 13. Persepsi PL terhadap Mekanisme pengelolaan pajak daerah yang dilakukan Pemerintah Daerah

\begin{tabular}{lcccc}
\hline $\begin{array}{c}\text { Alternatif } \\
\text { Jawaban }\end{array}$ & $\begin{array}{c}\text { Skor } \\
(\mathbf{x})\end{array}$ & $\begin{array}{c}\text { Frekuen } \\
\text { si (f) }\end{array}$ & f(x) & \% \\
\hline Sangat bagus & 5 & 6 & 6 & 31.6 \\
Bagus & 4 & 12 & 18 & 63.1 \\
Ragu-ragu & 3 & 1 & 19 & 5.3 \\
Tidak bagus & 2 & 0 & 19 & 0 \\
Sangat tidak & 1 & 0 & 19 & 0 \\
bagus & & 19 & 81 & 100 \\
Jumlah & \multicolumn{5}{c}{ Bagus } \\
\hline Interpretasi & \multicolumn{5}{c}{} \\
\hline
\end{tabular}

Mekanisme pengelolaan pajak daerah yang dilakukan Pemerintah Daerah sudah cukup memadai dalam hal penambahan pemasukan PAD sudah cukup baik, sehingga kriteria dalam skor range interpretasinya adalah Bagus

Tabel 14. Persepsi PL Bentuk Strategi peningkatan pajak reklame

\begin{tabular}{|c|c|c|c|}
\hline Jawaban (x) & $\begin{array}{c}\text { Frekue } \\
\text { nsi (f) }\end{array}$ & $\mathbf{f}(\mathbf{x})$ & $\%$ \\
\hline Sosialisasi & 6 & 6 & $\begin{array}{c}27 \\
3\end{array}$ \\
\hline $\begin{array}{l}\text { Peran aktif } \\
\text { petugas }\end{array}$ & 4 & 13 & $\begin{array}{c}18 . \\
3 \\
\end{array}$ \\
\hline
\end{tabular}

Bentuk strategi peningkatan pajak reklame persepsi para petugas lapangan menyatakan paling besar adalah bentuk strategi berupa sosialisasi dengan pesentase sebanyak 27,3 \%, di ikuti oleh peran aktif petugas sebanyak 18,3 \%. 
Tabel 15. Persepsi WP terhadap partisipasi pemasang iklan/reklame dalam Peningkatan PAD

\begin{tabular}{lcccc}
\hline \multicolumn{1}{c}{$\begin{array}{c}\text { Alternatif } \\
\text { Jawaban }\end{array}$} & $\begin{array}{c}\text { Skor } \\
(\mathbf{x})\end{array}$ & $\begin{array}{c}\text { Frekuensi } \\
\text { (f) }\end{array}$ & $\mathbf{f ( x )}$ & $\mathbf{\%}$ \\
\hline Sangat penting & 5 & 30 & 30 & 35.7 \\
Penting & 4 & 45 & 75 & 53.6 \\
Ragu-ragu & 3 & 8 & 83 & 9.5 \\
Tidak penting & 2 & 1 & 84 & 1.2 \\
Sangat Tidak & 1 & 0 & 84 & 0 \\
penting & \multicolumn{5}{c}{ Sangat Penting } \\
Jumlah & \multicolumn{5}{|c}{} \\
\hline $\begin{array}{l}\text { Tingkat kategori } \\
\text { Persepsi }\end{array}$ & \multicolumn{5}{c}{100} \\
\hline
\end{tabular}

Berdasarkan data Tabel Persepsi WP terhadap partisipasi pemasang iklan/reklame dalam peningkatan PAD hampir seluruh WP menyatakan bahwa partisipasi pemasang iklan/reklame untuk membayar pajak reklame adalah sangat penting untuk dapat meningkatkan penerimaan pajak.
Tabel 16. Persepsi Masyarakat BWP Terhadap Reward (Penghargaan) Dan Punishment (Hukuman) Kepada Para Wajib Pajak

\begin{tabular}{lcccc}
\hline $\begin{array}{c}\text { Alternatif } \\
\text { Jawaban }\end{array}$ & $\begin{array}{c}\text { Skor } \\
\text { (x) }\end{array}$ & $\begin{array}{c}\text { Frekue } \\
\text { nsi (f) }\end{array}$ & $\mathbf{f ( x )}$ & $\mathbf{\%}$ \\
\hline Sangat penting & 5 & 14 & 14 & 14 \\
Penting & 4 & 45 & 59 & 45 \\
Ragu-ragu & 3 & 29 & 88 & 29 \\
Tidak penting & 2 & 10 & 98 & 10 \\
Sangat Tidak & 1 & 2 & 100 & 2 \\
penting & 1 & 100 & 359 & 100 \\
Jumlah & \multicolumn{5}{c}{ Penting } \\
\hline Interpretasi & \multicolumn{5}{c}{} \\
\hline
\end{tabular}

Reward (penghargaan) dan punishment (hukuman) kepada para wajib pajak BWP menyatakan bahwa rewarddan punishmentpajak adalah penting dilakukan oleh Pemerintah Daerah, sebagai wujud penegakan hukum dan penghargaan terhadap masyarakat yang taat pajak.

\section{Analisis Internal Factor Evaluation(IFE) dan External Factor Evaluation(EFE)}

Tabel 17. Matriks Internal Factor Evaluation(IFE)

\begin{tabular}{|c|c|c|c|c|}
\hline No. & Faktor Strategis Internal & Bobot & Rating & Skor \\
\hline \multicolumn{2}{|r|}{ Kekuatan } & & & 1,675 \\
\hline 1 & Kelengkapan kelembagaan penyelenggaraan pajak reklame & 0,105 & 3 & 0,279 \\
\hline 2 & Adanya Perda Nomor 25 Tahun 2011 tentang Pajak Reklame & 0,137 & 4 & 0,480 \\
\hline 3 & Besarnya Dukungan dari Anggaran & 0,131 & 3 & 0,436 \\
\hline 4 & Jumlah SDM di bidang pajak reklame & 0,137 & 4 & 0,480 \\
\hline \multicolumn{2}{|r|}{ Kelemahan } & \multicolumn{3}{|r|}{1,550} \\
\hline 1 & $\begin{array}{l}\text { Kompetensi SDM dalam perencanaan potensi subyek dan obyek pajak } \\
\text { reklame }\end{array}$ & 0,144 & 4 & 0,527 \\
\hline 2 & $\begin{array}{l}\text { Masih adanya variasi kemampuan SDM dalam penyelenggaraan } \\
\text { (pengumpulan, pengelolaan dan pelayanan) pajak reklame }\end{array}$ & 0,111 & 3 & 0,315 \\
\hline 3 & $\begin{array}{l}\text { Terbatasnya sarana dan prasarana dalam penunjang penyelenggaraan } \\
\text { pajak reklame }\end{array}$ & 0,111 & 3 & 0,315 \\
\hline \multirow[t]{2}{*}{4} & Koordinasi antara SKPD penyelengaraan pelayanan pajak reklame & 0,124 & 3 & 0,393 \\
\hline & Jumlah & 1,00 & & 3,225 \\
\hline
\end{tabular}

Sumber : data primer (diolah)

Matriks IFE menggambarkan berbagai faktor internal yang terdapat dalam suatu unit organisasi. Matriks IFE mempunyai nilai yang dibobot antara nilai 0,0 (tidak penting) sampai dengan 1,0 (terpenting) dengan nilai rating antara nilai 1 (kelemahan utama) sampai dengan nilai 4 (kekuatan utama) dengan jumlah skor rata-rata 2,5.Pada perhitungan IFE yang telah didapat mempunyai skor 3,225, menunjukan bahwa kekuatan iternal secara keseluruhan memiliki posisi yang tinggi, sehingga harus dapat di maksimalkan potensinya untuk dapat mendukung peningkatan pendapatan pajak reklame di Kabupaten Bogor.Matriks EFE menggambarkan berbagai faktor internal yang terdapat dalam suatu unit organisasi. Matriks EFE mempunyai nilai yang dibobot antara nilai 0,0 (tidak penting) sampai dengan 1,0 (terpenting) dengan nilai rating antara nilai 1 (kelemahan utama) sampai dengan nilai 4 (kekuatan utama) dengan jumlah skor rata-rata 2,5. 
Tabel 18. Matriks External Factor Evaluation (EFE)

\begin{tabular}{|c|c|c|c|c|}
\hline No & Faktor Strategis Eksternal & Bobot & Rating & Skor \\
\hline \multicolumn{2}{|r|}{ Peluang } & & & 2,07 \\
\hline 1 & Potensi dan kontribusi ekonomi yang besar & 0,16 & 4 & 0,62 \\
\hline 2 & Meningkat dan berkembangnya WP & 0,15 & 4 & 0,56 \\
\hline 3 & Meningkatnya kepatuhan WP & 0,15 & 4 & 0,51 \\
\hline 4 & Luasnya potensi titik pemasangan Reklame & 0,13 & 3 & 0,38 \\
\hline \multicolumn{2}{|r|}{ Ancaman } & \multicolumn{3}{|r|}{1,596} \\
\hline 1 & $\begin{array}{l}\text { Masih kurangnya kesadaran Masyarakat tentang Pajak } \\
\text { Reklame }\end{array}$ & 0,14 & 3 & 0,47 \\
\hline 2 & $\begin{array}{l}\text { Secara geografis lokasi kabupaten Bogor yang diapit oleh } \\
\text { Kota Bogor dan Kota Depok }\end{array}$ & 0,14 & 3 & 0,47 \\
\hline 3 & Adanya kebijakan pemanfaatan badan jalan Pemerintah & & & \\
\hline 4 & Kebijakan Pelayanan Pajak Kota Bogor & 0,09 & 2 & 0,20 \\
\hline & Jumlah & 1,00 & & 3,668 \\
\hline
\end{tabular}

Sumber : Data Primer (diolah)

Pada perhitungan EFE yang telah didapat mempunyai skor 3,668 menunjukan bahwa kekuatan eksternal secara keseluruhan memiliki posisi yang kuat yang dapat memanfaatkan peluang-peluang yang ada serta dapat meminimalkan pengaruh dari ancaman yang merupakan kekuatan eksternal.

\section{Analisis Internal-Eksternal (IE)}

Pada Matrik IE parameter yang digunakan meliputi parameter kekuatan internal dan pengaruh eksternal yang dihadapi. Total skor IFAS dikelompokkan dalam tiga kelas yaitu lemah (skor $1-2$ ) rata - rata $(2-3)$ serta kuat $(3-4)$ dengan demikian akan diperoleh 9 kuadran alternatif strategi.

\begin{tabular}{|c|c|c|c|c|c|}
\hline & & & \multicolumn{3}{|c|}{ Total Nilai IFE : 3,225 } \\
\hline \multirow{5}{*}{ 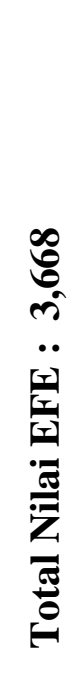 } & \multirow[b]{3}{*}{$\begin{array}{l}\text { Tinggi } \\
(3,00- \\
4,00)\end{array}$} & & $\begin{array}{c}\text { Kuat } \\
(3,00-4,00) \\
\end{array}$ & $\begin{array}{c}\text { Rata-rata } \\
(2,00-2,99) \\
\end{array}$ & $\begin{array}{c}\text { Lemah } \\
(1,00-1,99) \\
\end{array}$ \\
\hline & & 4,0 & 3,0 & 2,0 & 1,0 \\
\hline & & 3,0 & $\begin{array}{l}\text { 1. Tumbuh dan } \\
\text { Bina }\end{array}$ & $\begin{array}{l}\text { 2. Tumbuh dan } \\
\text { Bina }\end{array}$ & $\begin{array}{l}\text { 3. Pertahankan } \\
\text { dan Pelihara }\end{array}$ \\
\hline & $\begin{array}{c}\text { Rata-rata } \\
(2,00- \\
2,99)\end{array}$ & 2,0 & $\begin{array}{l}\text { 4. Tumbuh dan } \\
\text { Bina }\end{array}$ & $\begin{array}{l}\text { 5. Pertahankan } \\
\text { dan Pelihara }\end{array}$ & $\begin{array}{c}6 . \\
\text { Divestasi/Pane } \\
\mathrm{n}\end{array}$ \\
\hline & $\begin{array}{c}\text { Rendah } \\
(1,00- \\
1,99) \\
\end{array}$ & 1,0 & $\begin{array}{l}\text { 7. Pertahankan } \\
\text { danPelihara }\end{array}$ & $\begin{array}{l}\text { 8. Divestasi/ } \\
\text { Panen }\end{array}$ & $\begin{array}{c}9 . \\
\text { Divestasi/Pane } \\
\mathrm{n}\end{array}$ \\
\hline
\end{tabular}

Gambar 2. Matrik Internal-Eksternal (IE) 


\section{Tahap Keputusan dan Rancangan Program Strategi Peningkatan Pendapatan Pajak Reklame di Kabupaten Bogor}

Penentuan strategi merupakan tahap selanjutnya dari perumusan strategi dengan menggunakan analisis Quantitative Strategic Planning Matrix (QSPM). Analsisis QSPM dilakukan dengan cara memberikan nilai kemenarikan relatif (attractive scor $=$ AS) pada masing-masing faktor internal maupun eksternal. Strategi yang mempunyai total nilai kemenarikan relatif (Total Attractive Score=TAS) yang tertinggi adalah merupakan prioritas strategi.

Setelah dilakukan perhitungan dan analisis, di peroleh hasil analisis QSPM dalam perumusan prioritas strategi peningkatan pendapatan pajak reklame di Kabupaten Bogor, sebagai berikut :

Tabel 21. Strategi Peningkatan Pendapatan Pajak Reklame Di Kabupaten Bogor

\begin{tabular}{|c|c|c|c|}
\hline No & Strategi & Skor & Ranking \\
\hline 1 & $\begin{array}{l}\text { Melakukan penataan birokrasi dan manajemen pelayanan } \\
\text { penyelenggaraan pajak reklame secara lebih simple demi } \\
\text { kemudahan masyarakat }\end{array}$ & 6,820 & 5 \\
\hline 2 & $\begin{array}{l}\text { Memberikan reward/penghargaan dan punishment/hukuman } \\
\text { kepada masyarakat yang membayar pajak sesuai ketentuan }\end{array}$ & 6,963 & 3 \\
\hline 3 & $\begin{array}{l}\text { Membuka UPT Dipenda dan UPT DKP secara tersebar di seluruh } \\
\text { wilayah kabupaten Bogor untuk mempermudah pelayanan dan } \\
\text { penataan/pengawasan }\end{array}$ & 6,784 & 8 \\
\hline 4 & $\begin{array}{l}\text { Membangun kerjasama yang saling menguntungkan antara } \\
\text { Pemerintah, swasta dan masyarakat }\end{array}$ & 6,794 & 7 \\
\hline 5 & $\begin{array}{l}\text { Penambahan kualitas dan kuantitas SDM ditunjang oleh } \\
\text { perbaikan sarana prasarana penyelenggaraan pajak reklame }\end{array}$ & 6,813 & 6 \\
\hline 6 & $\begin{array}{l}\text { Melakukan sosialisasi dan penyuluhan secara berkesinambungan } \\
\text { untuk meningkatkan kesadaran masyarakat }\end{array}$ & 7,146 & 1 \\
\hline 7 & Meningkatkan koordinasi dan kerjasama antar SKPD & 6,887 & 4 \\
\hline 8 & Membangun system data yang valid dan akurat & 7,066 & 2 \\
\hline 9 & $\begin{array}{l}\text { Mewujudkan manajemen pelayanan pajak reklame secara mudah } \\
\text { dan cepat }\end{array}$ & 6,765 & 9 \\
\hline
\end{tabular}

\section{SIMPULAN DAN SARAN}

\section{Simpulan}

Berdasarkan analisis dan pembahasan terhadap strategi peningkatan pendapatan pajak reklame di Kabupaten Bogor, dapat disimpulkan beberapa hal sebagai berikut :

1. Penerimaan pajak reklame di Kabupaten Bogor selalu melebihi target yang ditetapkan, Tinggi nya rasio efektivitas pajak reklame pada tahun 2000-2012 terlihat bisa menunjukan tingginya upaya-upaya yang sudah dilakukan oleh pemerintah Kabupaten Bogor dalam mengintensifkan pemungutan pajak reklame dan Persentase efisiensi pajak reklame di Kabupaten Bogor pada tahun 2000-2012 terlihat baik. Tentu saja hal ini dipengaruhi oleh faktorfaktor jumlah anggaran, jumlah pegawai, jumlah peraturan dan jumlah wajib pajak yang mempengaruhi penerimaan pajak reklame di Kabupaten Bogor. Berdasarkan tabel uji parsial, anggaran, jumlah pegawai, peraturan dan wajib pajak memiliki pengaruh yang signifikan terhadap penerimaan pajak reklame pada taraf nyata $10 \%$. Hal ini dikarenakan nilai $\mathrm{p}$ lebih kecil dari 0,1 sehingga tolak H0.

2. Berdasarkan persepsi WP terhadap partisipasi pemasang iklan/reklame untuk membayar pajak dalam 
Peningkatan pendapatan pajak reklame adalah sangat penting, dengan tingkat pembayaran pajak sebanyak $25 \%$. Dengan harapan bahwa bahwa pelayanan pemungut pajak yang dilakukan kepada WP harus lebih baik dan perlunya ada kepastian hukum dalam pengelolaan pajak reklame yang harus terus menerus pula dilakukan sosialisasi secara berkesinambungan terhadap masyarakat mengenai pajak daerah serta adanya Pemberian penghargaan (reward) dan hukuman (punishment) kepada para wajib pajak. Untuk kemudahan WP metode pembayaran pajak yang diinginkan oleh adalah metode pembayaran pajak Langsung tunai dibayar sendiri ke loket Dinas Pendapatan Daerah, dengan alternative pembayaran transfer melalui Bank Jabar.

3. Manajemen penyelenggaraan pajak reklame yang sudah dilakukan terdapat beberapa kendala yang sangat penting yaitu, kurangnya data yang akurat karena keterbatasan kemampuan aparat pemerintah daerah serta masih kurang nya kesadaran masyarakat, padahal dalam melaksanakan pendataan kriteria yang sangat mendasar adalah harus tepat dan akuaratnya subyek dan obyek pajak, dasar hukum pajak yang merupakan payung hukum pelaksanaan beserta penerapannya secara tegas dan kemampuan petugas dari pihak pemerintah daerah yang bisa mengelola penyelenggaraan pajak sangat penting.

4. Rancangan Kebijakan dan strategi peningkatan pendapatan pajak reklame di Kabupaten Bogor adalah sebagai berikut:

a. Melakukan sosialisasi dan penyuluhan secara berkesinambungan untuk meningkatkan kesadaran masyarakat;

b. Membangun sistem data yang valid dan akurat;

c. Memberikan reward/penghargaan dan punishment/hukuman kepada masyarakat yang membayar pajak sesuai ketentuan;

d. Meningkatkan koordinasi dan kerjasama antar SKPD; dan

e. Melakukan penataan birokrasi dan manajemen pelayanan penyelenggaraan pajak reklame secara lebih simple demi kemudahan masyarakat.

\section{Rekomendasi Kebijakan}

Berdasarkan hasil pembahasan dan analisasi dalam strategi peningkatan pendapatan pajak reklame di Kabupaten Bogor, kebijakan yang perlu dipertimbangkan adalah :

1. Pemerintah Kabupaten Bogor perlu mengidentifikasi potensi sumbersumber pajak reklame secara riil sehingga dapat digunakan sebagai dasar dalam dalam penentuan target tahun berikutnya. Target-target pajak reklame sebelumnya dapat dinilai tidak sesuai dengan kondisi riilnya dan rendah, walaupun tingkat efektivitas pajak reklame cenderung selalu lebih besar dari seratus persen, tetapi dalam persepsi responden pemerintah daerah menurut survey Adanya persepsi satu orang yang menjawab tidak realistis serta satu orang pula yang menjawab sangat tidak realistis terhadap potensi pajak reklame mencerminkan bahwa sebenarnya target potensi pajak reklame di Kabupaten Bogor masih jauh dari harapan atau kenyataan yang sebenarnya. Perlunya segera pembenahan sistem informasi dan administrasi data yang valid dan terinci mengenai obyek, subyek, wajib pajak dan potensi wajib pajak reklame dalam pelaksanaan manajemen pajak reklame, sehingga diharapkan data tersebut dapat menjadi dasar perhitungan potensi target yang lebih riil dan mendekati realisasi sebenarnya dengan meningkatkan peran serta masyarakat secara umum.

2. Pemerintah Kabupaten Bogor perlu mempunyai program secara berkesinambungan dalam sosialisasi 
dan penyuluhan mengenai pajak reklame serta penegakan hukumnya, berupa reward/penghargaan dan punishment/hukuman terhadap masyarakat yang taat pajak ataupun lalai terhadap kewajiban pajak nya tersebut secara seimbang. Tentunya dukungan anggaran dan SDM yang berkualitas sangat dibutuhkan dalam pelaksanaan program strategi ini.

3. Pemerintah Kabupaten Bogor harus mempunyai program yang menciptakan manajemen pelayanan publik sebagai penyelenggaraan pajak reklame yang menerapkan good governance dan costumer focus. Walaupun unit kerja yang mengelola pajak reklame terdiri atas tiga SKPD diharapkan tidak sampai membuat masyarakat menjadi terbebani ketika akan melakukan proses memanfaatkan ruang reklame di Kabupaten Bogor dengan memasang iklan yang di bawa nya dan menjadi WP potensial. Dengan dukungan peningkatan pengetahuan dan wawasan SDM baik kualitas maupun kuantitasnya secara bertahap melalui program formal maupun informal yang tentunya harus di dukung oleh anggaran secara memadai.

\section{DAFTAR PUSTAKA}

Daryanto, Ariefdan Yundy Hafizrianda. (2010). Model-Model Kuantitatif untuk Perencanaan Pembangunan Ekonomi Daerah Konsep dan Aplikasi. IPB Press. Bogor.

Darwin. 2010. Pajak Daerah dan Retribusi Daerah. Mitra Wacana Media. Jakarta.

Effendi, Mohamad Agil. 2011. Optimalisasi Pajak Daerah dan Retribusi Daerah Untuk Meningkatkan Pendapatan Asli Daerah (PAD) di Kabupaten Sidoarjo (Tesis). Pascasarjana Universitas Pembangunan Nasional Veteran Jawa Timur.

Hamdani Mochamad Adam. 2007. Optimalisasi Peningkatan
Pendapatan Pajak Restoran di Kota

Depok (Tesis). Sekolah

Pascasarjana Institut Pertanian Bogor.

Landiyanto. A. 2005. Kinerja Keuangan dan Strategi Pembangunan di Era Otonomi Daerah: Studi Kasus Kota Surabaya, Cures Working Paper no. 05

Lutfi. A. 2002. Pemanfaatan Kebijakan Desentralisasi Fiskal Berdasarkan UU 34 tahun 2000 oleh Pemda untuk Menarik Pajak Daerah dan Retribusi Daerah: Studi Kasus di Kota Bogor.

Lutfi. A. 2006. "Penyempurnaan Administrasi Pajak Daerah dan Retribusi Daerah: Suatu upaya dalam optimalisasi penerimaan PAD”, Jurnal Ilmu Administrasi dan Organisasi: Bisnis \& Birokrasi, Volume XIV, Nomor 1, Januari 2006. Departemen Ilmu Administrasi, Fakultas Ilmu Sosial dan Ilmu Politik. Universitas Indonesia

Mardiasmo. 2009. Kebijakan Desentralisasi Fiskal di Era Reformasi. Kompas. Jakarta

Mahmudi. 2010. Manajemen Keuangan Daerah. Erlangga Jakarta.

Munir, Dasril. 2004. Kebijakan dan Manajemen Keuangan Daerah. YPAPI. Yogyakarta.

Riduansyah, Mohammad. 2003. Kontribusi Pajak Daerah Dan Retribusi Daerahterhadap Pendapatan Asli Daerah (PAD) Dan Anggaran Pendapatan Dan Belanja Daerah (APBD) Guna Mendukung Pelaksanaan Otonomi Daerah (Studi Kasus Pemerintah Daerah Kota Bogor). Sosial Humaniora. Vol. 7, No. 2, Desember (2003). Pusat Pengembangan dan Penelitian. Fakultas Ilmu Sosial dan Ilmu Politik. Universitas Indonesia. Depok.

R.F David. 2002. Manajemen Strategis: Konsep. Alih Bahasa Alexander Sindoro. PT. Prenhalindo. Jakarta 
Syahruddin. 2006. Desentralisasi Fiskal: Perlu Penyempurnaan Kebijakan dan Implementasi Yang Konsisten.

Sudirman, I Wayan. 2011. Kebijakan Fiskal dan Moneter: Teori dan Emperikal. Mitra Wacana Media. Jakarta

Sidik, Machfud. 2002. Orasi Ilmiah Optimalisasi Pajak Daerah dan Retribusi Daerah Dalam Rangka Meningkatkan Kemampuan Keuangan Daerah. Direktur Jenderal Perimbangan Keuangan Pusat dan Daerah, Departemen Keuangan, Jakarta.

Yulianti, Anita. 2010. Analisa Upaya Pengumpulan Pajak Reklame Papan. Billboard dan Megatron Di Kota Depok. (tesis). Fakultas Ekonomi Program Magister Perencanaan dan Kebijakan Publik ekonomi Keuangan Negara Dan Daerah. Universitas Indonesia. Depok.

Undang-Undang Nomor 32 Tahun (2004) tentang Pemerintahan Daerah

Undang-Undang Nomor 33 Tahun (2004) tentang Perimbangan Keuangan antara Pusat dan Daerah

Undang-Undang Nomor 28 Tahun (2009) tentang Pajak dan Retribusi Daerah

Peraturan Pemerintah Nomor 38 Tahun (2007) tentang Pembagian Urusan Pemerintahan Antara Pemerintah, Pemerintahan Daerah Provinsi, dan Pemerintahan Daerah Kabupaten/ Kota

Peraturan Menteri Keuangan Nomor 245/PMK.07/2010 tentang Peta Kapasitas Fiskal Daerah

Peraturan Daerah Kabupaten Bogor tentang APBD Kabupaten Bogor tahun 2003-2010

Peraturan Daerah Kabupaten Bogor tentang LPJP APBD Kabupaten Bogor tahun 2003-2010

Peraturan Daerah Kabupaten Bogor Nomor 6 Tahun 2004 tentang Penyelenggaraan Reklame

Peraturan Daerah Kabupaten Bogor Nomor 8 Tahun 2011 tentang
Pembentukan, Organisasi dan Tata Kerja Dinas Pendapatan Daerah Peraturan Daerah Kabupaten Bogor Nomor 25 Tahun 2011 tentang Pajak Reklame 


\section{Lampiran 1. MATRIKS SWOT}

\begin{tabular}{|c|c|c|}
\hline & STRENGTH & WEAKNESS \\
\hline $\begin{array}{c}\text { External Factor Evaluation } \\
\text { (EFE) }\end{array}$ & $\begin{array}{l}\text { 1. } \begin{array}{l}\text { Eksistensi dari unit kerja dalam } \\
\text { organisasi pemda } \\
\text { adanya } \\
\text { sebagai } \\
\text { penda }\end{array} \\
\text { 2. } \begin{array}{l}\text { Dasar hukum yang pasti untuk } \\
\text { pemungutan pajak reklame }\end{array} \\
\text { berdasarkan Perda No. } 25 \\
\text { Tahun 2011 tentang Pajak } \\
\text { Reklame; } \\
\text { 3. Adanya konsistensi dukungan } \\
\text { anggaran dari APBD dalam } \\
\text { penyelenggaran manajemen } \\
\text { pajak reklame; } \\
\text { Terdapat jumlah SDM aparatur } \\
\text { pemda di bidang pajak reklame. }\end{array}$ & 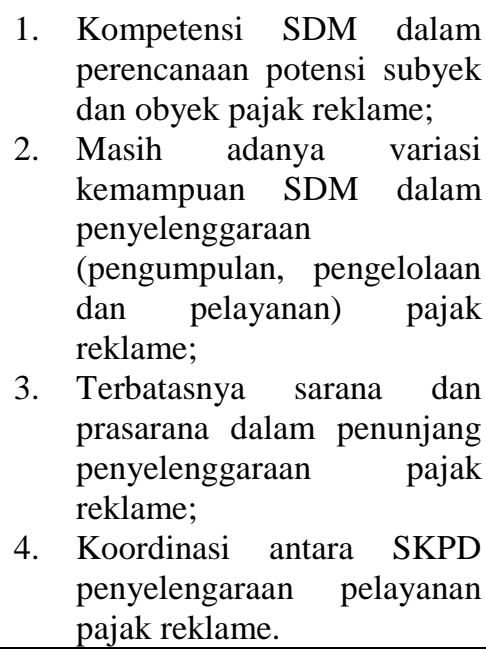 \\
\hline $\begin{array}{l}\text { OPPORTUNITY } \\
\text { 1. Adanya potensi dan kontribusi } \\
\text { ekonomi yang besar, sehingga } \\
\text { mendorong ingkat } \\
\text { perkembangan iklan/reklame } \\
\text { bagi masyarakat; } \\
\text { 2. Meningkat dan berkembangnya } \\
\text { Wajib pajak, } \\
\text { 3. Meningkatnya kepatuhan wajib } \\
\text { pajak, } \\
\text { Luasnya potensi titik } \\
\text { pemasangan reklame, secara } \\
\text { geografis luas wilayah } \\
\text { Kabupaten Bogor yang sangat } \\
\text { luas pada dasarnya sudah } \\
\text { merupakan suatu peluang untuk } \\
\text { dapat dimanfaatkan setiap sisi } \\
\text { ruangnya terutama bagi iklan/ } \\
\text { reklame komersil. }\end{array}$ & $\begin{array}{l}\text { S - O } \\
\text { 1. Melakukan penataan birokrasi } \\
\text { dan manajemen pelayanan } \\
\text { penyelenggaraan pajak reklame } \\
\text { secara lebih simple demi } \\
\text { kemudahan masyarakat. (S1, } \\
\text { S2, S3, S4, O1, O2, O3, O4) } \\
\text { 2. Memberikan } \\
\text { reward/penghargaan dan } \\
\text { punishment/hukuman kepada } \\
\text { masyarakat yang membayar } \\
\text { pajak sesuai ketentuan. (S1, S2, } \\
\text { S3, S4, O1, O2, O3) } \\
\text { Membuka UPT Dipenda dan } \\
\text { UPT DKP secara tersebar di } \\
\text { seluruh wilayah kabupaten } \\
\text { Bogor untuk mempermudah } \\
\text { pelayanan dan penataan/ } \\
\text { pengawasan. (S1, S2, S3, S4, } \\
\text { O1, O2, O3, O4) }\end{array}$ & $\begin{array}{l}\text { W - O } \\
\text { 1. Membangun kerjasama yang } \\
\text { saling menguntungkan } \\
\text { antara Pemerintah, swasta } \\
\text { dan masyarakat (W1, W2, } \\
\text { W3, W4, O1, O2, O3, O4) } \\
\text { 2. Penambahan kualitas dan } \\
\text { kuantitas SDM ditunjang } \\
\text { oleh perbaikan sarana } \\
\text { prasarana penyelenggaraan } \\
\text { pajak reklame (W1, W2, } \\
\text { W3, W4, O1, O2, O3, O4) }\end{array}$ \\
\hline \begin{tabular}{ll}
\multicolumn{1}{c}{ THREAT } \\
1. \\
Masih kurangnya kesadaran WP \\
tentang Pajak Reklame; \\
2. Secara geografis lokasi \\
kabupaten Bogor yang diapit \\
oleh Kota Bogor dan Kota \\
Depok; \\
3. Adanya kebijakan pemanfaatan \\
badan jalan Pemerintah Provinsi \\
ataupun Pemerintah Pusat; \\
Kebijakan Pelayanan Pajak \\
Kota Bogor
\end{tabular} & 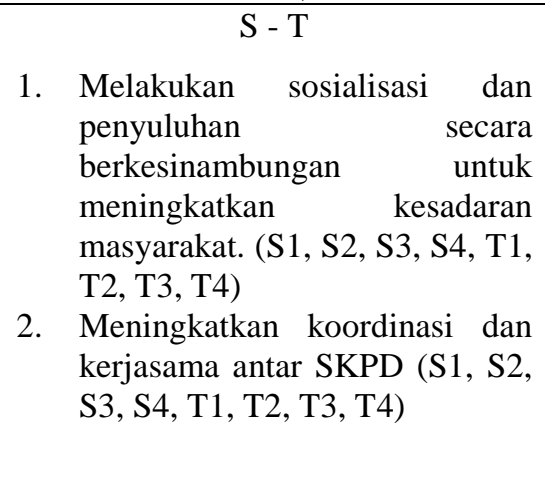 & $\begin{array}{l}\text { W - T } \\
\text { 1. Membangun system data } \\
\text { yang valid dan akurat (W1, } \\
\text { W2, T1, T2, T3, T4) } \\
\text { 2. Mewujudkan manajemen } \\
\text { pelayanan pajak reklame } \\
\text { secara mudah dan cepat } \\
\text { ((W1, W2, W3, W4, T1, T2, } \\
\text { T3, T4) }\end{array}$ \\
\hline
\end{tabular}

